\title{
Apropriate Agronomic Practices for Pest and Disease Management
}

\author{
Negalur R. B..$^{*}$, G. S. Guruprasad ${ }^{2}$, Gowdar S. B. ${ }^{3}$ and Narappa G. ${ }^{4}$ \\ ${ }^{1}$ AICRP on weed management, ${ }^{2}$ AICRP on Rice, ${ }^{3}$ ARS, ${ }^{4} \mathrm{KVK}$, MARS, UAS, Raichur, Karnataka (584 104), India
}

\section{Corresponding Author}

Negalur R. B.

e-mail: tushberkipilli@rediffmail.com

\author{
Article History \\ Manuscript No. AR1801 \\ Received in $4^{\text {th }}$ March, 2017 \\ Received in revised form $18^{\text {th }}$ March, 2017 \\ Accepted in final form $7^{\text {th }}$ April, 2017
}

\begin{abstract}
Pesticides play important role in agricultural production by means of increasing crop yield and farmer's income. The indiscriminate use of chemicals has resulted in a reduction of biodiversity of natural enemies, outbreak of secondary pests, development of resistance to pesticides and contamination of food and ecosystem, Agronomic measures of pest management involves variations in usual farm operations which are being usually preventive and indirect, they are the cheapest of all the control measures The principle involved in the agronomic management of insect pest and disease is purposeful manipulation of the environment to make it less favorable for their incidence by exerting economic control on the pest or at least reducing their rate of increase/damage. Due to sustained increasing problems from massive applications of pesticides, like insect resistance to pesticides, resurgence of pests, pollution of food and feed, health hazards, toxicity towards plants and animals and environmental pollution. One way to minimize these effects is use of biotechnological tools for alleviating biotic stresses, which explore how the tools of biotechnology can be used in pest management for sustainable crop production and environmental conservation. Another way is through cultural control including all those techniques that will make the environment less favorable for pests to develop or multiply, but which still favors crop production. Insect pest and disease management in its broadest sense includes everything that makes the life difficult for insects that kill them or prevents their increase and make it laborious for them to spread about the world.
\end{abstract}

Keywords: Agronomic practices, pest, disease, purposeful manipulation, crop rotation

\section{Introduction}

Pest and disease management has played vital role in doubling food production in the last 40 years. Pesticides, as an important input in agricultural food production, have contributed enormously to the development of agriculture and food supply to mankind (Wang and Li, 2007). Present available data indicate that $33 \%$ losses of the potential crop yield due to the insect pests attack were avoided and recovered worldwide because of chemicals application (Liu et al., 2002). Increased agricultural pesticide usage nearly doubled the harvest of food crop from $42 \%$ of the theoretical worldwide yield in 1965 to $70 \%$ of the theoretical yield by 1990. Unfortunately, still $30 \%$ of the theoretical yield is still being lost because, the use of effective pest management methods are not applied uniformly around the world and it still is not and without the usage of agricultural pesticides, $70 \%$ of crop yield could have been lost to pests (Oerke, 2005).

The intensity of crop protection has increased considerably as extended by a $15-20$ fold increase in the amount of pesticides used worldwide (Oerke, 2005). Over the last century, agricultural production has steadily increased, mainly due to advances in crop breeding, improved nutrient availability, and much better crop protection. However, these improvements have often caused environmental problems, such as water pollution, trace gas emissions, or soil degradation. More sustainable practices are needed to minimize the environmental impact of agricultural production and effective land use (Ludwig et al., 2011). In chemical control the decline in the natural enemy composition in rice ecosystem by 3.5 times and cotton by 12 times clearly indicates the ill effects of pesticides (Dhaliwal and singh, 1985).

Global food production must increase by $50 \%$ to meet the projected demand of the world's population by 2050 (Chakraborty and Newton, 2011). Thus, we need to grow food on even less land, with less water, using less energy, fertilizer and pesticide than we use today (Popp et al., 2013). Currently the yield losses caused by insect pests, diseases caused by pathogens and weeds are the major challenges to agricultural production (Oerke and Dehne, 2004). Globally, on an average $35 \%$ of potential crop yield is lost before harvest of the crops due to pests (Oerke, 2005). Earlier literature suggest that increasing vegetation biodiversity in agro ecosystems can reduce the impact of pests and diseases by the following mechanisms: (1) resource dilution and stimulo-deterrent diversion, (2) disruption of the spatial cycle, (3) disruption 
of the temporal cycle, (4) allelopathy effects, (5) general and specific soil suppressiveness, (6) crop physiological resistance, (7) conservation of natural enemies and facilitation of their action against aerial pests and (8) direct and indirect architectural/ physical effects (Ratnadass et al., 2012).

\section{Agronomic Components of Pest and Disease Management}

\subsection{Tillage/Plowing}

Tillage has been an integral part of production agriculture and is synonymous with seedbed preparation and post weed control (Reicosky and Allmaras, 2003). Tillage has also been important for insect and disease management through the burial of crop residue, despite the negative environmental effects of tillage, it remained an important tool for managing weeds before the planting of crops and after their emergence, but before full crop canopy (Gunsolus, 1990). Tillage was used to destroy perennial crops and weeds before seeding annual crops (Tripplett, 1985). The introduction of Glyphosate resistant (GR) crops in 1996 brought a technology that enabled many producers to adopt reduced tillage production systems (Wade at al., 2009). Smiley and Wilkins (1993) found that rhizoctonia root rot was more severe in barley than wheat especially in non-tilled soils and the continuous cropping of cereals enhanced the disease problem, as both crops were hosts for the pathogen. Spotted wilt (tomato spotted wilt tospovirus) incidence was $42 \%$ lower in reduced and minimum tillage systems than in conventional tillage systems and is now part of the recommended strategy to manage the disease (Johnson et al., 2001). Alternating between conventional and minimum tillage would pose less disease risk for Sclerotinia than long-term minimum tillage in lettuce at Salinas Valley of coastal California, USA (Jackson et al., 2004). Deep plowing results in exposure of propagules to elevated temperatures and physical killing of the pathogen and this can be regarded as dry soil solarization, summer plowing was effective at reducing populations of cyst nematodes and increasing wheat yield (Mathur et al., 1987). In an experiment at Salinas Valley, California, USA, Minimum tillage tended to decrease lettuce (Lactuca sativa) and broccoli (Brassica oleracea) yields, but was not associated with increased pest problems (Jackson et al., 2004). At Agriculture and Agri-Food Research Centre Saskatoon, Canada, for cereal crops, root disease incidence decreased with reduced tillage and new disease problems with take-all, rhizoctonia root rot and pythium root rot have not developed during the study period (Bailey, 2016).

\subsection{Selection of planting materials/varieties}

To provide more and better food to populations in both the southern and northern hemispheres in a sustainable manner there is a need for a shift from agrochemistry to agroecology (Deguine et al., 2008). Agroecology is based on the optimization of biological interactions and regulations in agroecosystems and its application to crop protection can be referred to as agroecological crop protection (Deguine et al., 2008). Selection of appropriate crop varieties may have a profound effect on crop-weed competition and varietal characteristics, like, taller plant height, size of flag leaf, higher leaf size, leaf area index, high specific leaf area during vegetative growth and allelopathic ability (Joshi et al., 2007; Bertholdsson and Brantestam, 2009) makes one variety more competitive with weeds than another. Resistance of the plant to insect is the property that enables the plant to avoid, tolerate or recover from injury by insect pest population. Mali and Patil (1993) noticed that least infestation of gram pod borer, legume pod borer and plume moth with mean percentage of pod infestation of $17.46 \%, 17.76 \%$ and $18.44 \%$ respectively, with variety T-21 in redgram. ICGS-65 a groundnut variety recorded lowest leaf miner infestation (5.4\%) whereas, TAG-24 was infested to the extent of 30.2\% (Jena et al., 1996). The cotton germplasm stocks like MMCV-5, Mahalaxmi, Krishna, Abadhita, TH-144, Sujatha, Suvin were identifed for boallroom resistance, whereas, supriya, LK-861 and kanchan were found to have resistance against whitefly (Sundarmurthy and Basu, 1992). Suraksha, Vikramarya, Shaktiman, Rasmi jaya, Lata were the rice varieties with multiple resistance to more than one pest (Krishnaiah, 1995). Lemerle et al. (1996) tested 250 genotypes of wheat for competitiveness against Lolium rigidum and concluded that strongly competitive genotypes had high early biomass accumulation with extensive leaf display. Elite cultivars of cowpea viz., IT90K-277-2, IT90K-734, IT93K-452-1 and IT93K-513-2 performed better, whereas IT86D-719, IAR-48 and Dan lla gave the poorest yields, when unsprayed at IITA Research Manjibir, Northern Nigeria (Asante et al., 2001).

Baliyan and Rao (2013) observed the yield, resistant to nematode, late blight and farmer's perception and concluded that among the six tomato varieties tested, Zeal is the best variety followed by FA 593 for pest and disease adaption and productivity in Botswana of South Africa. Andrew et al. (2015) also opined that early plant vigour and canopy architecture are the important traits in cereals imparting competitive ability against weed. Under the late sown condition of eastern Uttar Pradesh, wheat variety DBW-39 was found highly effective for suppression of weed growth, particularly during critical crop-weed competition period and recorded higher number of grain/earhead, biological yield and harvest index followed by K-0307 (Mani et al., 2016).

\subsection{Seed treatment}

The role of seed in agriculture sector is of prime importance in developing countries like India where the population and GDP (Gross Domestic Product) considerably depend on agriculture sector (Tyagi, 2012). The chemical control of pest and disease via soil/foliar application has its limitation such as high cost, selectivity, effect on target organisms, development of pest resistance, resurgence of pests, pollution of food and feed, health hazards, toxicity towards plants and animals, environmental pollution etc (Rahman et al., 2008). Considering these limitations with a growing world population, there has been a growing interest to develop such management practices/tools which alone or in combination with other practices could bring about a reasonably good degree of reduction of inoculums potential and at the same time ensure the sustainability of the production, cost 
effectiveness and healthy ecosystem and 'seed treatment' is one of these tools (Kumar, 2012). Seed treatment ranges from a basic dressing to coating and pelleting (ASF, 2010; Dubey, 2011). Seed treatment with Trichoderma harzianum along with soil amendment of poultry refuse and vermicompost offered better performance against damping off disease of potato and chilli. Seed treatment with $T$. harzianum followed by soil amendment might be suggested to control damping off disease complex of potato and chilli (Uddin et al., 2011).

Dry heat treatment (DHT), a powerful and agrochemical free means of inactivating seed borne virus and other pathogens has been extensively used for value added vegetable seeds in Korea, Japan, and some other countries (Lee et al., 2004). Thomas and Adcock (2004) reported that dry heat treatment for a period of $4-7$ days at $650{ }^{\circ} \mathrm{C}$ or up to 4 days at $700{ }^{\circ} \mathrm{C}$ reduce, possibly eradicate anthracnose infection in lupine seeds. Successful pathogen control achieved by Forsberg et al. (2005) by aerated heat treatment of seed against combined infections of $S$. nodorum and Fusarium spp, and for $T$. caries on wheat, infections of $D$. teres and $B$. sorokiniana on barley and infections of $D$. avenae and $U$. avenae on oat. Research efforts in alternatives methods to chemical crop protection are currently being addressed worldwide especially with regards to food safety and environmental sustainability (Nicholas and Steven, 2013). In green house experimrnt at TNAU, Tamil Nadu, Bacillus subtilis G1 could be considered as a promising alternative to synthetic chemical fungicides in the management of maize downy mildew and could be successfully exploited as a biocontrol agent within the framework of integrated disease management system (Sireesha and Velazhahan, 2016).

\subsection{Sowing/planting time}

The manipulation of planting time helps to minimize pest damage by producing asynchrony between host plants and the pest or synchronizing insect pest with their natural enemies. Hessian fly (Myotiola destructor) usually lays eggs in the upper surface of young winter wheat leaves. By delayed plating suitable host were not available until most of the over wintering adult flies emerges and die (Teetes, 1993). Rice planted on $15^{\text {th }}$ may had resulted in high percentage of infestation of mealy bug (30\%) compared to july transplated crop (Krishnaiah, 1995). From the production and protection point of view $15^{\text {th }}$ June was a suitable date of sowing of groundnut so that the damage due to leaf miner can be reduced to greater extent (Singh and Rawat, 1981). Sharma and Sharma (1999) reported that early sown fenugreek crop suffered least due to low powdery mildew inoculum potential and unfavorable weather conditions for pathogen whereas, late sown crop suffered more because of ready availability of inoculums buildup in early sown crop. Experiment conducted at the Teaching and Research Farm of Usmanu Danfodiyo University, Nigeria showed that planting early is the best way to achieve higher yield of onion of over $40 \mathrm{t} \mathrm{ha}^{-1}$ by transplanting in November increased the yield to $60.0 \mathrm{t} \mathrm{ha}^{-1}$ and it was observed that any transplanting done beyond December will produce very low yield due to severe attack of thrips (Ibrahim and Adesiyun, 2010). Sunflower crop sown during $\left.\right|^{\text {st }}$ Fortnight of July showed least powdery mildew PDI and slower disease progression than other dates of sowings and also increase in seed yield followed by crop sown on IId $^{\text {nd }}$ Fortnight of July, wherein the lesser PDI and slower rate of disease progression observed in contrast to higher PDI in crop sown during August, September and October months (Akhileshwari et al., 2012).

Kethran et al. (2014) reported based on the results of experiment on different sowing dates at Kunri, Mirpur Khas Sindh, Pakisthan, maximum mean aphids, thrips, jassids whitefly and fruit borer population of $0.527,3.68,0.46$, 5.49 and 0.427 leaf $^{-1}$ were found in SD4 (February $28^{\text {th }}$ ) and minimum of $0.36,1.83,0.01,3.41$ and 0.27 leaf $^{-1}$ were present in SD1 (January $15^{\text {th }}$ ) and green maximum chilli pod yield of $2.71 \mathrm{t} \mathrm{ha}^{-1}$ was produced in SD1 (January $15^{\text {th }}$ ) followed by $2.50 \mathrm{t} \mathrm{ha}^{-1}$ in SD2 (January $30^{\mathrm{th}}$ ) and minimum yield of 1.72 ha $^{-1}$ was achieved in SD4 (February $28^{\text {th }}$ ). Sujay and Giraddi (2014) reported from experiments conducted at the Main Agricultural Research Station, UAS, Dharwad, Karnataka, India. Significantly lower level of sucking pest and leaf curl index was observed in the interaction of July $15^{\text {th }}$ planting which recorded dry chilli yield $4.21 \mathrm{q} \mathrm{ha}^{-1}$ as against yield of $1.99 \mathrm{q}$ ha ${ }^{-1}$ sown June $30^{\text {th }}$. Similar pattern of treatment significance was observed in case of natural enemy population also.

\subsection{Plant spacing/geometry}

The plant spacing an important cultural factor, which influence the incidence of leaf hoppers, thrips and aphids. Sivagurnathan et al. (1998) noticed least number of leaf hopper in cotton plants which were planted at $60 \times 30 \mathrm{~cm}^{2}$ spacing. In contrast leaf hopper population was significantly more in widely spaced cotton $\left(75 \times 45 \mathrm{~cm}^{2}\right)$. Mathur et al. (2007) observed that at wider spacing of $45 \mathrm{~cm}$ seed per pod and 100 seed weight recorded an increase of 11.9 and $15.7 \%$, respectively in comparison to narrow spacing in mungbean. Singh et al. (2011) concluded that the sugarcane genotype CoLk 94184 was superior in yield, quality and its ratoonability over CoLk 97147 with the spacing requirement of $90 \mathrm{~cm}$. July end sown crop was found to have more 100 seed weight (3.50 $\mathrm{gm}$ ) in N-S direction (3.40 g) and closer spacing (3.42 g) than their counter parts of August $1^{\text {st }}$ sown crop with E-W direction under wide spacing, respectively (Singh et al., 2012).

The pigeonpea sown at $150 \times 90 \mathrm{~cm}^{2}$ spacing recorded significantly higher number of pods plant ${ }^{-1}$ as compared to $150 \times 60 \mathrm{~cm}^{2}$ spacing. However, the other yield attributes viz., 100 seed weight and number of seeds pod $^{-1}$ did not differ significantly due to different spacing (Saritha et al., 2012). Sujay and Giraddi (2014) reported significantly lower level of sucking pest and leaf curl index was observed in the $90 \times 60 \mathrm{~cm}^{2}$ spacing followed by $60 \times 60 \mathrm{~cm}^{2}$, whereas, it was higher in case of $60 \times 30 \mathrm{~cm}^{2}$. Significantly highest chilli yield was registered in $90 \times 60 \mathrm{~cm}^{2}$ spacing $\left(4.21 \mathrm{q} \mathrm{ha}^{-1}\right)$ whereas, the lowest chilli yield of $1.99 \mathrm{q} \mathrm{ha}^{-1}$ was registered in $60 \times 30 \mathrm{~cm}^{2}$ treatment from experiments conducted in Karnataka, India. Two years results of the study at CSIR-Crops Research Institute, Kumasi, 
Ghana showed high biomass and seed yield of chia (Salvia hispanica $\mathrm{L}$.) when the crop was planted at narrow row spacing of $0.5 \times 0.5 \mathrm{~m}^{2}$ consistently produced the highest biomass and seed yield in both years of the study (Yeboah et al., 2014). Among the four different planting geometry tried, square planting architect $30 \times 30 \mathrm{~cm}^{2}$ proved better $\left(3690.90 \mathrm{~kg}^{-1}\right)$ than other planting geometry in case of faba (Singh et al., 2015).

Planting geometry of $45 \times 15 \mathrm{~cm}^{2}$ resulted in maximum branches plant ${ }^{-1}$ (15.67), capsules plant ${ }^{-1}$ (38.00), seeds capsule $^{-1}$ (51.44), seed weight plant ${ }^{-1}$ (31.89 g), seed index $(2.83 \mathrm{~g})$, biological yield $\left(2301.23 \mathrm{~kg} \mathrm{ha}^{-1}\right)$, seed yield $(742.33$ $\mathrm{kg} \cdot \mathrm{ha}^{-1}$ ) and harvest index (30.44\%) followed by planting geometry of $60 \times 10 \mathrm{~cm}^{2}$ in all the parameters. However, minimum growth and yield traits of sesame were recorded under planting geometry of $30 \times 20 \mathrm{~cm}^{2}$ (Nadeem et al., 2015). The experiment conducted at Adisaptagram Block Seed Farm, Mogra, Hooghly, West Bengal, India to know the severity of late blight of potato (Phytophthora infestans) and from the results it was evident that the severity of the disease decreased with increase in spacing i.e. in spacing $50 \times 15 \mathrm{~cm}^{2}$ the severity of the disease was $92.06 \%$. But in case of spacing $60 \times 25 \mathrm{~cm}^{2}$ the severity of the disease was only $71.82 \%$ (Dey and Chakraborty, 2016)

\subsection{Crop rotation}

Crop rotation with non-host plants is the first general agronomic rule to avoid soil-borne diseases. Non host effects via increased plant species diversity (PSD) at the field level over time, disrupt the life cycle of soil-borne pests and diseases via belowground processes (Ratnadass et al., 2012). Neglecting crop rotation results in the enrichment of pest populations, the accumulation of toxic substances, the depletion of mineral nutrients, degradation in soil fertility and destruction of soil structure (Katan, 2010). Crop rotation deals with plant health in general rather than with controlling a specific disease, although a certain crop sequence might be more effective in reducing the incidence of a specific disease than others.

Although air borne diseases can also be avoided to some extent through crop selection and crop rotations that include some non host crops, this strategy is more effective for soil or residue borne pathogens (Krupinsky et al., 2002) with reduced mobility and dispersal ability and a limited life span of conservation forms. The most straight forward principle underlying rotation as a disease control strategy is that plant pathogen propagules have a lifetime in soils and rotation with non-host crops starves them out (Reid et al., 2001).

Crop rotation schemes at the land scape scale may affect natural enemy communities due to changes in spatial distribution of resources over time (Holland et al., 2005; Rusch et al., 2010). For instance, increasing crop diversity may be beneficial to natural enemies due to higher spatiotemporal availability of food or refuges at the landscape scale. Longer and more diverse crop rotation systems with a higher proportion of perennial crops may also reduce disturbance of natural predator communities (Jonsson et al., 2012).

\subsection{Irrigation and water management}

Soil moisture is an important factor in pest development because of its effect on plant growth and vigour. It alters the moisture content of the soil and consequently influences its aeration and temperature and these in turn affect the incidence of diseases through their impact on biotic and abiotic processes in the soil or foliage (Reference). Irrigation also affects disease incidence indirectly due to changes in the agricultural regime, such as intensification of cropping and changes in the date of sowing and growing seasons (Katan, 1996). Increasing or decreasing the moisture through irrigation may affect pest population by causing mechanical damage to their development, the rice mealy bug was found to be abundant in unirrigated field compared to frequently irrigated fields (Padhee et al., 1995).

Alternate wetting and drying at 10 days intervals starting from 35 days after transplanting drastically reduced brown plant hopper and white backed plant hoppers incidence in contrast to continuous flooding of water of $5 \mathrm{~cm}$ (Singh and Dhaliwal, 1994). Katan (2010) Cultural practices can be harnessed for the management of foliar and soil borne diseases by creating an environment which is favorable for the crop and unfavorable for the pathogen. Certain (Cultural practices) CPs, e.g. flooding and sanitation are used mainly for pest control while others, e.g. irrigation, can be used for both crop management and pest control.

Results of field experiment using system of rice intensification (SRI) techniques conducted in Chiba, Japan revealed that apart from higher water productivity it also showed a role of AWDI in minimizing pest and disease incidence, shortening the rice crop cycle, and also improving plant stand until harvest (Tejendra and Yamaji, 2010). Saritha et al. (2012) reported that two irrigations one at flower initiation and another at early pod formation stage significantly increased the yield components viz., number of pods plant ${ }^{-1}$ and test weight of pigeonpea as compared to control and one irrigation treatment. No irrigation treatment recorded significantly lower number of pods plant ${ }^{-1}$ over irrigation treatment. Dey and Chakraborty (2016) reported that the severity of late blight disease of potato could be minimized by reducing the depth of irrigation (i.e. $1 / 4$ of irrigation channel).

\subsection{Fertilizer application}

Nutrients are important for growth and development of plants and also microorganisms and they are important factors in disease control (Agrios, 2005). The increase in the level of nitrogen application resulted in the increase of aphid population in mustard (Singh et al., 1995). Higher fertilizer application especially, nitrogen resulted in more luxurious vegetative growth and makes the potato more vulnerable for weevil attack (Naik et al., 1996). Zinc application in the form of zinc chelate (Zn-EDTA) was superior than the application of zinc sulphate in reducing the rice green leaf hopper incidence (Padhee et al., 1995). in rice increase in the mealy bug infsation was noticed with corresponding increase in the nitrogen levels (Backialakshimi and Subramanian, 1996). 
It is believed that plants grown under conditions of low $\mathrm{N}$ availability are better defended against pathogens because there is an increase in the synthesis of defense related compounds (Wilkens et al., 1996; Hoffland et al., 2000). It has been frequently observed that $K$ reduces the incidence of various diseases such as bacterial leaf blight, sheath blight, stem rot, sesamum leaf spot in rice, black rust in wheat, sugary disease in sorghum, bacterial leaf blight in cotton, cercospora leaf spot in cassava, tikka leaf spot in peanut, red rust in tea, cercospora leaf spot in mungbean and seedling rot caused by Rhizoctonia solani (Sharma and Duveiller, 2004; Sharma et al., 2005). Shu et al. (2009) indicated that excess Zn made expression of vitellogenin gene downregulated and caused poor accumulation of egg yolk, which led to a reduction in egg numbers and failure of eggs to hatch. Kulagod et al. (2011) reported the higher level of nitrogen and phosphorus application supported higher blue beetle damage in paddy in an experimrnt conducted at ARS Mundgod, Uttara Kannada Karnataka.

Manganese fertilization can control a number of pathogenic diseases such as powdery mildew, downy mildew, take-all, tan spot and several others (Simoglou and Dordas, 2006). Application of higher dose of $30 \mathrm{~kg} \mathrm{Zn} \mathrm{ha}^{-1}$ to rice against stem bores incidence, markedly decreased infestation, while, applications at 20 and $25 \mathrm{~kg}$ permitted slightly more dead hearts and white heads incidence (Sarwar, 2011). Rice insect pests and diseases such as brown plant hopper, stem borer, leaf folder, blast, red stripped disease and Sheath blight of rice pests were positively related to increased nitrogen level application, with serious outbreak of insect pests and diseases (Chau et al., 2013).

\subsection{Cropping system}

The canopy of intercrop should have an effect on crop growth and also the insect pests incidence, the incidence of borer complex has been found ten times more in pigeonpea with intercrop as compared to sole crop (Bhatnagar, 1981). The incidence of leaf miner was comparatively low in groundnut + bajra intercrop as compared to sole crop (Muralibaskaran et al., 1990). Chickpea mix cropped with wheat, barley and ray resulted in reduced pod damage due to Helicoverpa armigerea but when, the same intercrops were grown with definite row proportion, the incidence of pod borer was found higher (Rathore and Nwanze, 1993). Kennady and Raveendran (1989) reported that groundnut+bajra intrcropping system registered low leaf hopper and thrips population and bud necrosis disease when they harvested groundnut with redgram, greengram, cowpea, sunflower, corn and sorghum as intercrops.

The experiments conducted under Co-ordinated pulse improvement project in 1981-82 indicated that intercropping reduced the incidence of borer complex to $26 \%$ as against $49 \%$ in sole crop of pigeonpea (Anonymous, 1982). Growing sorghum in association with cowpea or lab lab reduced the sorghum stem borer infestation. Chand and sharma (1977) also found that growing maize in association with legumes reduced the Chilo partellus damge in maize-cotton crop in rotation with non-hosts like raagi, maize, groundnut or soybean minimizes the incidence of pests (Simwat, 1994). It is expected that insect pests will generally become more abundant as temperatures rise as a result of range extensions and phonological changes. This abundance will be accompanied by higher rates of population development, growth, migration, and overwintering (Cannon, 1998; Bale, 2002). Habitat management is one method used within agricultural systems to alter habitats to improve the availability of the resources and natural enemies required for optimal performance (Landis et al., 2000).

Greater natural enemy presence has been observed in the more diverse and shaded agroforestry systems and increased bird diversity and density have been shown to reduce herbivore plant damage through greater insectivorous bird predation (Perfecto et al., 2004). Sule (2013) found that intercropping cowpea with sorghum significantly reduced aphid and thrips population than in sole cowpea varieties at the age of 30 and 40 days. From the two year study to evaluate the effect of intercropping of potato (Solanum tuberosum L.) with onion (Allium cepa L.) on whitefly and aphids'(Myzus persicae Sulz) and (Aphis gossypii Glover) infestation in potato fields indicated that intercropping significantly reduced potato plant infestation with whitefly by 42.7 to $51.3 \%$ while it was $62.69 \%$ reduction with aphids during the two successive winter seasons than when potato plants were cultivated alone (Sharaby et al., 2015).

\section{Conclusion}

Agronomic measures of insect pest and disease management generally involve variation in the usual farm operation, they do not usually require any extra out lay or equipment to carry out pest management, these measures are usually preventive and they are indirect in effect, they do not pose the environmental problems. Hence, feasible and possible agronomic measures suiting to the particular niche for particular single or group of insect pest and disease infesting predominant crops should be considered as the first ditch difference around which to build other options for the pest control.

\section{References}

Agrios, N.G., 2005. Plant Pathology. $5^{\text {th }}$ (Edn.), ElsevierAcademic Press, 635.

Akhileshwari, S.V., Amaresh, Y.S., Naik, M.K., Kantharaju, V., Shankergoud, I., Ravi, M.V., 2012. Effect of dates of sowing on powdery mildew severity and yield of Sunflower. Karnataka Journal of Agricultural sciences 25(1), 129-130.

Andrew, I.K.S., Storkey, J., Sparkes, D.L., 2015. A review of the potential for Competitive cereal cultivars as a tool in integrated weed management. Weed Research 55(3), 239-248.

Anonymous, 1982. Consolidated report on kharif pules 1981-82 (Entomolgy) All India Co-ordinated pulses Improvemnt Project Directorate of pulses Research, 
Kanpur.

Asante, S.K., Tamo, M., Jacki, L.E.N., 2001. Integrated management of insect pests using elite cultivars, date of planting and minimum insecticide application. African Crop Science Journal 9(4), 655-665.

ASF, 2010. National code of practice for the use of seed treatments. Australian Seed Federation Limited, 1-7. Retrieved: September 4, 2014 from http://www.asf. asn.au/userfiles.

Backialakshmi, T., Subramanian, A., 1996. Effect of different levels of nitrogen and different organic manures on rice mealy bug (Brevennia rehi) infrestation. Indian journal Entomology 58(3), 250-253.

Bailey, K.L., 2016. Diseases under conservation tillage systems, Canadian Journal of Plant Science, 76(4), 635-639.

Bale, J.S., 2002. Herbivory in global climate change research: Direct effects of rising temperature on insect herbivores. Global Change Biology 8, 1-16.

Baliyan, S.P., Rao, M.S., 2013. Evaluation of Tomato Varieties for Pest and Disease Adaptation and Productivity in Botswana, International Journal of Agricultural and Food Research 2(3), 20-29.

Bertholdsson, N.O., Brantestam, K.A., 2009. A century of Nordic barley breeding-effects on early vigour root and shoot growth, straw length, harvest index and grain weight. Eurasia Journal of Agronomy 30, 266-274.

Bhatnagar, V.S., 1981. Entomological observations on inter cropped pigeonpea in selected villages of Andra pradesh and Maharastra, Progeress Reports-6 Cropping system, Entomology ICRISAT Patancheru, Hyderabad.

Cannon, R.J.C., 1998. The implications of predicted climate change for insect pests in the UK, With emphasis on nonindigenous species. Global Change Biology 4, 785-796.

Chand, P., Sharma, N.N., 1977. Proceeding of Indian National Science Academy 43(3), 108-114.

Chakraborty, S., Newton, A.C., 2011. Climate change, plant diseases and food security: An overview. Plant Pathology 1, 2-14.

Chau, L.M., Cat, H.D., Ben, P.T., Phuong, L.T., Cheng, j., Heong, K.L., 2003. Impacts of nutrition management on insect pests and diseases of rice. Omonrice 11, 93-102.

Dey, S., Chakraborty, A., 2016. Influence of agronomic practices on severity of late blight of potato (Phytophthora infestans). Journal of Applied and Natural Science 8(3), 1302-1305.

Deguine, J.P., Ferron, P., Russell, D., 2008. Protection des cultures: de l'agrochimie a l'agroécologie (Ed.), Quae, Versailles.

Dhaliwal, G.S., Singh, B., 1985. Novel concepts and furture of pesticides in third world. In: Pesticides Their ecological impact in developing countries, Common wealth publishers, New Delhi, India, 335-363.

Mani, D., Singh, M.K., Prasad, S.K., 2016. Varieties and mulching influence on Weed growth in wheat under Indo-Gangetic plain of India. Journal of Applied and Natural Science 8(2), 515-520.

Forsberg, G., Johnsson, L., Lagerholm, J., 2005. Effects of aerated steam seed treatment on cereal seed-borne diseases and crop yield. Journal of Plant Diseases and Protection 12(3), 247-256.

Gunsolus, J. L., 1990. Mechanical and cultural weed control in corn and soybeans. American Journal of Alternative Agriculture 5, 114-119.

Hoffland, E., Jegger, M.J., Van Beusichem M.L., 2000. Effect of nitrogen supply rate on disease resistance in tomato depends on the pathogen. Plant Soil 218, 239-247.

Holland, J.M., Thomas, C.F.G., Birkett, T., Southway, S., Oaten, H., 2005. Farm-scale spatiotemporal dynamics of predatory beetles in arable crops. Journal of Applied Ecology 42, 1140-1152.

Ibrahim, N.D., Adesiyun, A.A., 2010. Effects of Transplanting Dates and Insecticide Frequency in the Control of Thrips tabaci Lindeman (Thysanoptera:Thripidae) on Onion (Allium cepa L.) in Sokoto, Nigeria. Journal of Agricultural Science 2(2), 239-249.

Jackson, L.E., Ramirez, I., Yokota, R., Fennimore, S.A., Koike, S.T., Henderson, D.M., Chaney, W.E., Calderon, F.J., Klonsky, K., 2004. On-farm assessment of organic matter and tillage management on vegetable yield, soil, weeds, pests, and economics in California. Agriculture, Ecosystems and Environment 103, 443-463.

Jena, B.C., Kukiz, B., Parida, A.K., 1996. Incidence of leaf miner in groundnut varieties. Indian journal of Enotmology 58(1), 383-385.

Johnson, W.C., Brenneman, T.B., Baker, S.H., Johnson, A.W., Sumner, D.R., Mullinix, B.G., 2001. Tillage and Pest Management Considerations in a Peanut-Cotton Rotation in the Southeastern Coastal Plain, Agronomy Journal 93, 570-576.

Jonsson, M., Buckley, H.L., Case, B.S., Wratten, S.D., Hale, R.J., Didham, R.K., 2012. Agricultural intensification drives landscape-context effects on host-parasitoid interactions in agroecosystems. Journal of Applied Ecology 49, 706-714.

Joshi, A.K., Chand, R., Arun, B., Singh, R.P., Ortiz, R., 2007. Breeding crops for reduced-tillage management in the intensive rice-wheat systems of South Asia. Euphytica 153, 135-151.

Katan J., 1996. Cultural practices and soil-borne disease management. In: Utkhede, R.S., Gupta, V.K. (Eds.), Management of Soil Borne Diseases, 100-122. Kalyani Publishers, New Delhi, India.

Katan, J., 2010. Cultural approaches for disease management: present status and future prospects. Journal of Plant Pathology 92(4), S4.7-S4.9.

Kennady, F.J.S., Raveendran, J.S., 1989. Oilseeds Newsletter 3(4) Directorate of Extension Newsletter 3(4) Directorate of Extension, New Delhi.

Kethran, M.R., Sun, Y.Y., Khan, S., Baloch, S.U., Wu, L.L., Lu Yang Yang, T.T., Hu, Z., Salam, A., Iqbal, S., Ali, S., Bashir, W., 2014. Effect of Different Sowing Dates on Insect Pest Population of Chillies (Capsicum annuam L.). Journal of Biology, Agriculture and Healthcare 4(25), 196-214.

Krishnaiah, K., 1995. Insect Pest Management in Rice 
Final Technical Report, Directorate of Rice Research Rajendranagar, Hyderabad, India, 21-23.

Dubey, K., 2011. Insecticide and fungicide seed treatment. Retrieved: 1 September, 2014, from http:// agropedia. iitk.ac.in/content/insecticide-and-fungicideseedtreatment.

Krupinsky, J.M., Bailey, K.L., McMullen, M.P., Gossen, B.D., Turkington, T.K., 2002. Managing plant disease risk in diversified cropping systems. Agronomy Journal 94, 198-209.

Kulgod, S.D., Hegde, M.G., Nayak, G.V., Vastrad, A.S., Hugar, P.S., 2011. Influence of fertilizer on the incidence of insect pests in paddy. Karnataka Journal of Agricultural Sciences 24(2), 241-243.

Landis, D.A, Wratten, S.D, Gurr, G.M., 2000. Habitat management to conserve natural enemies of arthropod pests in agriculture. Annual Review of Entomology 45, 175-201.

Lemerle, D., Verbeek, B., Cousens, R.D., Coombes, N.E., 1996. The potential for selecting wheat varieties strongly competitive against weeds. Weed Research 36, 505-513.

Liu, C.J., Men, W.J., Liu, Y.J., Zhang, H., 2002. Soil pollution by pesticides and polluted soil biorestoration. Agricultural System Science and Integrated Study 4, 295-297.

Ludwig, B., Geisseler, D., Michel, K., Joergensen, R. G., Schulz, E., Merbach, I., Raupp, J., Rauber, R., Hu, K., Niu, L.,Liu, X., 2011. Review article: effects of fertilization and soil management on crop yields and carbon stabilization in soils. Agronomy for Sustainable Development 31, 361-372.

Mali, M.S., Patil, S.P., 1993. Field screening of genotypes of pigeonpea against pod borers. Indian Journal of Entomology 55(1), 191-193.

Mathur, B.N., Handa, D.K., Swarup, G., 1987. Effect of deep ploughing on the cereal cyst nematode, Heterodera avenae and yield of wheat in Rajasthan India. Indian Journal of Nematology 17, 292-295.

Mathur, N., Singh, J., Bohra, S., Bohra, A., Vyas, A., 2007. Agronomic evaluation of promising genotypes of mungbean under hyper arid conditions of Indian Thar Desert. International Journal of Agricultural Research 2(6), 537-544.

Muralibaskaran, R., Thangavelu, S., Balsubramanian, G., 1990. Influence of intercrop on the incidence of leaf miner (Aproaerma modieella) in groundnut. Journal of Oilseed Research 7, 143-146.

Nadeem, A., Kashani, S., Ahmed, N., Buriro, M., Saeed, Z., Mohammad, F., Ahmed, S., 2015. Growth and Yield of Sesame (Sesamum indicum L.) under the Influence of Planting Geometry and Irrigation Regimes. American Journal of Plant Sciences 6, 980-986.

Naik, M.T., Revanna, H.P., Patil, S.U., 1996. Effect of spacing and fertilizer on incidence of sweet potato weevil. Karnataka journal of Agricultural Sciences 9(4), 682-684.

Nicholas, K.R., Steven P.C.G., 2013. Assessment of nonchemical seed treatment methods in organic seeds: Assessment of physiological sensitivity of seeds to physical treatment. Publisher-LAP Lambert Academic Publishing (22 January, 2013), 88.

Oerke, E.C., Dehne, H.W., 2004. Safe guarding productionlosses in major crops and the role of crop protection. Crop Protection 23, 275-285.

Oerke, E.C., 2005. Crop losses to pests. Journal of Agricultural Sciences 144, 31-43.

Padhee, A.K., Mishra, D.S., Singh, V.N., 1995. Influence of zinc application on the incidence of rice green leaf hoppers. Indian Journal of Entomology 57(1), 10-14.

Perfecto, I., Vandermeer, J.H., Bautista, G.L, Nuñez, G.I, Greenberg, R., Bichier, P., Langridge, S., 2004. Greater predation in shaded coffee farms: The role of resident Neotropical birds. Ecology 85, 2677-2681.

Popp, J., Peto, K., Nagy, J., 2013. Pesticide productivity and food security. A review. Agronomy for Sustainable Development 33, 243-255.

Rahman, M.M.E., Ali, M.E., Ali, M.S., Rahman, M. M., Islam, M.N., 2008. Hot water thermal treatment for controlling seed-borne mycoflora of maize. International Journal of Sustainable Crop Production 3(5), 5-9.

Ratnadass, A., Fernandes, P., Avelino, J., Habib, R., 2012. Plant species diversity for sustainable management of crop pests and diseases in agroecosystems: a review. Agronomy for Sustainable Development 32, 273-303.

Rathore, Y.S., Nwanze, K.F., 1993. Pest management through cultural practices. Innovative methods. In: Sharma, H.C., Rao, M.V. (Eds.), Pests and pest management in IndiaThe Changing Scenario, 216-228.

Reicosky, D.C., Allmaras, R.R., 2003. Advances in tillage research in North American cropping systems. In: Shrestha, A. (Ed.), Cropping Systems: Trends and Advances. New York, NY: Haworth, 75-125.

Reid, L.M., Zhu, X., Ma, B.L., 2001. Crop rotation and nitrogen effects on maize susceptibility to gibberella (Fusarium graminearum) ear rot. Plant Soil 237, 1-14.

Rusch, A., Valantin, M.M., Sarthou, J.P., Roger, E.J., 2010. Biological control of insect pests in agroecosystems: effects of crop management, farming systems and semi-natural habitats at the landscape scale a review. Advances in Agronomy 109, 219-260.

Kumar, S., 2012. Cultural approaches for plant disease management. Research \& Reviews:Journal of Agricultural Science and Technology 1(2), 12-21.

Saritha, K.S., Pujari, B.T., Basavarajappa, R., Naik, M.K., Rameshbabu, Desai, B.K., 2012. Effect of irrigation, nutrient and planting geometry on yield, yield attributes and Economics of pigeonpea. Karnataka Journal Agricultural Science 25(1), 131-133.

Sarwar, M., 2011. Effects of Zinc fertilizer application on the incidence of rice stem borers (Scirpophaga species) (Lepidoptera: Pyralidae) in rice (Oryza sativa L.) crop. Journal of Cereals and Oilseeds 2(5), 61-65.

Lee, S.H., Kim, J.S., Lee, J.M., 2004. Moisture contents in bottle gourd seeds during dry heat treatment and subsequent germination. Horticulture Science 39(4), 758-759.

Sharma, R.C., Duveiller, E., 2004. Effect of helminthosporium 
leaf blight on performance of timely and late-seeded wheat under optimal and stressed levels of soil fertility and moisture. Field Crop Research 89, 205-218.

Sharaby, A., Rahman, H.A., Moawad, S.S., 2015. Intercropping system for protection the potato plant from insect infestation. Ecologia balkanica 7(1), 87-92.

Sharma, S., Duveiller, E., Basnet R., Karki C.B., Sharma R.C., 2005. Effect of potashfertilization on helminthosporium leaf blight severity in wheat, and associated increases in grain yield and kernel weight. Field Crop Research 93, 142-150.

Sharma, R.N., Sharma, S.K., 1999. Influence of time of sowing and spacing levels on powdery mildew and seed yield in pea cv. Arkel. Journal of Mycology and Plant Pathology 32(1), 117-119.

Shu, Y.H., Gao, Y.Y., Sun, H.X., Zou, Z.W., Zhou, Q.A., Zhang, G.R., 2009. Effects of Zinc exposure on the reproduction of Spodoptera litura Fabricius (Lepidoptera:Noctuidae). Ecotoxicology and Environmental Safety 72(8), 21302136.

Simoglou, K., Dordas, C., 2006. Effect of foliar applied boron, manganese and zinc on tan spot in winter durum wheat. Crop Protection 25, 657-663.

Simwat. G.S., 1994. Modern concepts in insect pest management in cotton. In: Dhaliwal, G.S., Arora, R. (Eds.)Trends in agricultural Insect pest Management, Commonwealth publishers, New Delhi, India, 186-237.

Singh, S.P., Sandhu, S.K., Dhaliwal, L.K., Singh, I., 2012. Effect of planting geometry on microclimate, growth and yield of mungbean (Vigna radiata L.). Journal of Agricultural Physics 12(1), 70-73.

Singh, A.K., Bhat, B.P., Sundram, P.K., Gupta, A.K., Singh, D., 2015. Planting geometry to optimize growth and productivity in faba bean (Vicia faba L) and soil productivity. Journal of Environmental Biology 34, 117-122.

Singh, D.P., Rawat, R.R., 1981. Field efficiency of some foliar insecticides against some major insect pests of groundnut in Madhya Pradesh. JNKVV Research Journal $15,41-42$.

Singh, J., Dhaliwal, G.S., 1994. Changing status of insect pests in intensive agriculture. In: Dhaliwal, G.S., Hansra, B.S., Jerath, N. (Eds.), Changing scenario of our enviroment. Punjab Agricultural University, Ludhianan, India, 241-251.

Singh, R.P., Yazadni, S.S., Verma, G.D., Singh, V.N., 1995. Effect of different levels of nitrogen, phosphorus and potash on aphid infestation and yield of mustard. Indian journal of Entomology 57(1), 18-21.

Singh, A.K., Lal, M., Singh, S.N., 2011. Agronomic performance of new sugarcane genotypes under different planting geometries and $\mathrm{N}$ levels. Indian Journal of Sugarcane Technology 26(1), 6-9.

Sireesha, Y., Velazhahan, R., 2016. Biological control of downy mildew of maize caused by Peronosclerospora sorghi under environmentally controlled conditions, Journal of applied and natural science 8(1), 279-283.
Sivagurunathan, P., David, P.M.M., Jamagarajan, A., 1998. Influence of plant spacing on the incidence of major sucking pests of cotton. Journal of Cotton Research and Development 12(2), 257-261.

Smiley, R.W., Wilking, D.E., 1993. Annual spring barley growth, yield, and root rot in high and low residue tillage systems. Journal of Production Agriculture 6, 270-275.

Sujay, Y.H., Giraddi, R.S., 2014. Investigation on the Effects of Planting Time and Plant Geometry on the Activity of Sucking Pests of Chilli Capsicum annuum L. Global Journal of Science Frontier Research 14 (4), 1-9.

Sule, H., 2013. Effect of variety and intercropping on two major cowpea [Vigna unguiculata (L.) Walp] field pests in Mubi, Adamawa State, Nigeria. International Journal of Agricultural Research and Development 1(5), 108-109.

Sundermurthy, V.T., Basu, A.K., 1992. Management of cotton insect pests in poly crop system in India. Outlook on Agriculture 14, 79-82.

Tejendra, C., Yamaji, E., 2010. The effects of irrigation method, age of seedling and spacing on crop performance, productivity and water-wise rice production in Japan. Paddy and water environment 8(1), 81-90.

1993. The environmental control of insect using planting time and plant spacing. In: Teetes, G.T. (Ed.), Pimetal D, CRC Handbook of pent management in Agriculture CBS Publishers and Distributers New Delhi, 169-182.

Thomas, G.J., Adcock, K.G., 2004. Exposure to dry heat reduces anthracnose infection of lupin seed. Australian Plant Pathology 33, 537-540.

Tripplett, G.B.J., 1985. Principles of weed control for reducedtillage corn production. In: Wiese, A.F. (Ed.), Weed Control in Limited Tillage Systems. Champaign, IL: Weed Science Society of America, 6-40.

Tyagi, V., 2012. India's agriculture: Challenges for growth \& development in present scenario. International Journal of Plant \& Soil Science 2(5), 116-128.

Uddin, M.M., Akhtar, N., Islam M.T., Faruq, A.N., 2011. Effect of Trichoderma harzianum and Some Selected Soil Amendment Against Damping off Disease Complex of Potato and Chilli. The Agriculturists 9(1\&2), 106-116.

Wang, S.N., Li, W.C., 2007. Pesticides application status, effects and strategies in China. Modern Preventive Medicine 20, 3853-3855.

Yeboah, S., Owusu, D.E., Lamptey, J.N.L., Mochiah, M.B., Lamptey, S., Oteng-Darko, P., Adama, I., Appiah-Kubi, Z., Agyeman, K., 2014. Influence of Planting Methods and Density on Performance of Chia (Salvia hispanica) and its Suitability as an Oilseed Plant. Agricultural Science 2(4), 14-26.

Wade, A.G., Shaw, D.R., Kruger, G.R., Johnson, W.G., Weller, S.C., Young, B.G., Wilson, R.G., Owen, M.D.K., Jordan, D., 2009. Survey of tillage trends following the adoption of glyphosate-resistant crops. Weed Technology 23, 150-155.

Wilkens, R.T., Spoerke, J.M., Stamp, N.E., 1996. Differential response of growth and two Soluble phenolics of tomato to resource availability. Ecology 77, 247-258. 